\title{
Trends in arrivals and prices of potato in Pune market
}

K. S. DAUNDKAR, SUPRIYA D. KASHID, U.S. BONDAR AND H.P. THAKARE

Received : 19.07.2016; Revised : 21.08.2016; Accepted : 08.09.2016

\begin{abstract}
The market information relating to market prices and arrivals over a period of time helps the farmers to take decision about the future production pattern and sale of agricultural commodities in the market during specific period. For estimating trends in arrivals and prices of potato the exponential type function was fitted to data. The result revealed that, the ACGR for arrivals and prices of potato in the Pune market for the period from 2003-04 to 2012-13 were exhibited to 2.14 and 8.51 per cent per annum, respectively. The ACGR for arrivals and prices was found positive and significant.Seasonal indices of arrivals and prices of potato noticed highest during the month of October (129.58). The lowest indices of arrivals were noticed in the month of March (76.75), because this period was lean period. In case of prices indices was noticed highest in the month of November (121.82). While lowest in March (74.06) followed by Feb., January and April.
\end{abstract}

KEY WORDS : Growth rates, Seasonal indices, Arrivals, Prices

How to cite this paper : Daundkar, K.S., Kashid, Supriya D., Bondar, U.S. and Thakare, H.P. (2016). Trends in arrivals and prices of potato in Pune market. Internat. J. Com. \& Bus. Manage, 9(2) : 175-178, DOI: 10.15740/HAS/IJCBM/9.2/175-178. 